\title{
Toxicities and Recurrences after Co-60 High-Dose-Rate Brachytherapy for Cervical Cancer in a Tertiary Government Hospital in the Philippines
} \author{
Edilberto Joaquin Fragante Jr. ${ }^{1}$ \\ ${ }^{1}$ Division of Radiation Oncology, Department of Radiology, \\ University of the Philippines-Philippine General Hospital, Ermita, \\ Manila, The Philippines \\ 2Division of Gynecologic Oncology, Department of Obstetrics \\ and Gynecology, University of the Philippines-Philippine General \\ Hospital, Ermita, Manila, The Philippines \\ ${ }^{3}$ College of Medicine, University of the Philippines Manila, \\ The Philippines
}

Reno Eufemon Cereno ${ }^{1}$ Bernadette Yap ${ }^{2}$ Lorelei Chavez ${ }^{1}$ Maria Julieta Germar ${ }^{2} \quad$ Michelle Ann B. Eala ${ }^{3}$

Asian J Oncol 2021;7:126-133.

\begin{abstract}
Address for correspondence Reno Eufemon Cereno, MD, MPM, Division of Radiation Oncology, Department of Radiology, University of the Philippines-Philippine General Hospital, Ermita, Manila 1000, The Philippines (e-mail: rcereno.md@gmail.com).
\end{abstract}

\section{Abstract}

\section{Keywords}

- brachytherapy

- cervical cancer

- HDR brachytherapy

- Philippine experience

- radiation oncology
Introduction Despite the rising popularity of high-dose-rate (HDR) brachytherapy and use of Co-60 in the country, local data on brachytherapy outcomes are lacking. The study reviewed the incidence of toxicities and recurrences in patients with cervical cancer treated with Co-60 intracavitary HDR brachytherapy in a tertiary government hospital in the Philippines.

Methods Records of patients with cervical cancer who completed external beam radiotherapy (EBRT) and brachytherapy from 2016 to 2018 were reviewed. Patient-related (age, smoking history, body mass index, histology, stage, mass size) and treatment-related (overall treatment time [OTT], EBRT machine used, brachytherapy fractionation, dose prior to midline shielding/central tumor dose [CTD]) parameters were analyzed for possible associations with the incidence of toxicities and recurrences. Results One hundred and sixty-three patients were identified and reviewed for baseline characteristics. Patients who had inadequate follow-up ( $<90$ days) were excluded in the analysis of outcomes. Among the remaining 132 patients, median follow-up duration was 389 days. Gastrointestinal (GI) and genitourinary (GU) toxicities were present in $19.7 \%(n=26)$ and $1.5 \%(n=2)$, respectively. Recurrence was noted in $31.8 \%$ $(n=42)$. The most commonly involved sites of locoregional and distant recurrence was the uterocervix ( $n=16,59.3 \%)$ and para-aortics ( $n=42,31.8 \%)$, respectively. CTD was significantly associated with toxicities $(p=0.03)$, while OTT was borderline significantly associated with recurrence $(p=0.06)$.

Conclusion We present outcomes of GI and GU toxicities, and locoregional and distant recurrences after chemoradiation and Co-60 HDR brachytherapy in a tertiary government hospital in the Philippines. Our study suggests that CTD was significantly associated with incidence of toxicities, while OTT was weakly associated with recurrence. Interventions should be made to control these factors, especially in high-volume, low-resource cancer centers. published online

May 14, 2021
DOI https://doi.org/

$10.1055 / \mathrm{s}-0041-1729344$ ISSN 2454-6798
(C) 2021. Spring Hope Cancer Foundation \& Young Oncologist Group of Asia.

This is an open access article published by Thieme under the terms of the Creative Commons Attribution-NonDerivative-NonCommercial-License, permitting copying and reproduction so long as the original work is given appropriate credit. Contents may not be used for commercial purposes, or adapted, remixed, transformed or built upon. (https://creativecommons.org/licenses/by-nc-nd/4.0/). Thieme Medical and Scientific Publishers Pvt. Ltd. A-12, 2nd Floor, Sector 2, Noida-201301 UP, India 


\section{Introduction}

The current standard of care in the management of most cases of cervical cancer is external beam radiotherapy (EBRT) concurrent with chemotherapy and intracavitary brachytherapy. ${ }^{1,2}$ Brachytherapy allows for tumor dose escalation while limiting the dose received by organs-at-risk (OARs), such as the bladder and the rectum. ${ }^{3}$ When added to EBRT, brachytherapy improves primary complete remission, survival, and recurrence rates for patients with cervical cancer. $^{4}$

High-dose-rate (HDR) brachytherapy has superseded low-dose-rate (LDR) brachytherapy over the last decade since the former permits treatment in the outpatient setting, limits radiation exposure to the staff, and allows for optimization for a more conformal dose distribution, which is appropriate in the era of image guidance, among many other advantages. ${ }^{5}$ However, the optimal fractionation regimen for HDR brachytherapy, which employs the use of multiple hypofractionated radiotherapy fractions, remains unsettled. From a radiobiological perspective, more hypofractionated regimens are expected to produce more late effects. In 1991, Orton et al concluded that fractionation in HDR brachytherapy significantly influenced toxicities. Complication rates were significantly higher in regimens that utilized $>7$ Gy per fraction as compared with those that used otherwise. ${ }^{6}$ Some of the regimens listed by the American Brachytherapy Society (ABS) guidelines are $7 \mathrm{~Gy} \times 4,6 \mathrm{~Gy} \times 5,5 \mathrm{~Gy} \times 6$, and $5.5 \mathrm{~Gy} \times 5$ fractions, ${ }^{7}$ although a wide practice variation exists internationally. ${ }^{8}$

Toxicities arising from chemoradiation (CRT), including brachytherapy, are primarily gastrointestinal (GI) and genitourinary (GU) by virtue of proximity of these organs to the cervix. To lessen the risk of GI and GU toxicities, the ABS recommends a cumulative dose limit of $\leq 75 \mathrm{~Gy}$ to the rectum and the sigmoid, and $\leq 90 \mathrm{~Gy}$ to the bladder in the delivery of a 2-Gy-radiobiologically equivalent (EQD2) cumulative radiotherapeutic dose of 80 to $90 \mathrm{~Gy}$ to the tumor. ${ }^{7}$ In a pooled analysis of clinical outcomes for HDR brachytherapy for cervical cancer by the American Brachytherapy Task Group, the range of toxicities after CRT was 1 to $11 \%$ for late GI and 2 to $20 \%$ for late GU toxicities. For the late gynecologic toxicity, only 1 of the 16 prospective trials reported $9 \%$ for CRT effects. ${ }^{9}$

Iridium 192 (Ir-192) is among the most commonly used radioisotopes in HDR brachytherapy for cervical cancer due to its small size and high specific activity. Most trials on the safety and efficacy of HDR brachytherapy in the treatment of cervical cancer utilized Ir-192 as the brachytherapy radioisotope. One of the disadvantages in using Ir-192, however, is its relatively short half-life, which warrants replacement every 74.3 days. $^{3}$ The recent availability of cobalt 60 (Co-60) sources with the same geometric and dosimetric properties as the more traditional Ir-192 sources makes the former an option in HDR brachytherapy and is more appropriate in low-resource brachytherapy facilities where frequent and timely procurement of radioisotopes could be a problem. Limited studies on the use of Co-60 sources in HDR brachytherapy for cervical cancer are, however, available in the literature. ${ }^{10}$

\section{Objective}

The study aimed to review and report the incidences of GI and GU toxicities and recurrences in patients with cervical cancer who were treated with intracavitary HDR brachytherapy using a cobalt-60 remote afterloading system between September 2016 and September 2018 in a tertiary hospital in the Philippines.

Specifically, the study aimed to:

- Determine the incidence of GI and GU toxicities.

- Determine the incidence of recurrences after brachytherapy.

- Determine the overall treatment time (OTT) of patients with cervical cancer in the brachytherapy unit of our institution, defined as days elapsed from first day of EBRT to last fraction of brachytherapy.

- Determine the institutional treatment gap between the last day of EBRT and first fraction of brachytherapy, if any.

- Analyze the relationship between patient-related (i.e., smoking history, body mass index) and treatment-related (i.e., OTT, EBRT machine use, use of midline shielding, brachytherapy fractionation scheme used) factors, and occurrence of recurrences and toxicities.

\section{Significance}

This study was undertaken to provide baseline institutional data on the incidence of GI and GU toxicities and recurrences in patients with cervical cancer treated with intracavitary HDR brachytherapy using a cobalt-60 remote afterloading system. The results can establish the safety of using cobalt-60 instead of the more popularly used iridium-192. This is important in low-resource, high-volume radiotherapy facilities since cobalt-60 has a longer half-life and will thus require less frequent procurement of sources. The results can also guide future institutional policies to streamline brachytherapy services and to improve the oncologic outcomes of patients with cervical cancer.

\section{Methods, Study Design, and Sampling}

A case-control study design was employed to clarify any association between the treatment (HDR brachytherapy) and the outcomes, as well as other potential risk factors (e.g., age, duration of treatment). Prior to its implementation, the study secured approval from the institutional research ethics board.

All women with biopsy-confirmed cervical cancer who underwent HDR brachytherapy from September 2016 until September 2018 (period of 2 years) in our institution were included in the study. The inclusion and exclusion criteria are listed in - Table 1. Selecting all patients within the period of observation was done to ensure the representativeness of the sample and reduce the possibility of selection bias, since 
Table 1 Criteria for patient selection

\begin{tabular}{|c|c|}
\hline Inclusion & Exclusion \\
\hline $\begin{array}{l}\text { Biopsy-confirmed squamous cell } \\
\text { carcinoma or adenocarcinoma of } \\
\text { the cervix }\end{array}$ & $\begin{array}{l}\text { Systemic metastases at } \\
\text { time of diagnosis (stage } \\
\text { IVB) }\end{array}$ \\
\hline Stage I-III by FIGO 2009 staging & $\begin{array}{l}\text { Documented invasion of } \\
\text { bladder or rectum (stage } \\
\text { IVA) }\end{array}$ \\
\hline $\begin{array}{l}\text { Age at initial diagnosis between } 19 \\
\text { and } 80 \text { years }\end{array}$ & $\begin{array}{l}\text { Recurrent cervical cancer } \\
\text { at baseline }\end{array}$ \\
\hline $\begin{array}{l}\text { Patients under the charity service } \\
\text { of UP-PGH }\end{array}$ & Previous pelvic surgery \\
\hline $\begin{array}{l}\text { Underwent concurrent chemora- } \\
\text { diation (pelvic EBRT } \pm \text { para-aortic } \\
\text { coverage, concurrent with cisplatin) } \\
\text { for cervical cancer }\end{array}$ & $\begin{array}{l}\text { Previous chemotherapy or } \\
\text { radiotherapy }\end{array}$ \\
\hline \multirow[t]{3}{*}{$\begin{array}{l}\text { Underwent HDR brachytherapy and } \\
\text { completed the number of intended } \\
\text { fractions }\end{array}$} & $\begin{array}{l}\text { Underwent LDR } \\
\text { brachytherapy }\end{array}$ \\
\hline & $\begin{array}{l}\text { Patients who did not } \\
\text { complete their prescribed } \\
\text { number of brachytherapy } \\
\text { fractions }\end{array}$ \\
\hline & $\begin{array}{l}\text { Documented uterine } \\
\text { perforation at the time of } \\
\text { brachytherapy }\end{array}$ \\
\hline
\end{tabular}

Abbreviations: EBRT, external beam radiotherapy; FIGO, International Federation of Gynecology and Obstetrics; HDR, high-dose-rate; LDR, low-dose-rate; UP-PGH, University of the Philippines-Philippine General Hospital.

there were no local data available at that time to ascertain the association between the exposure and outcomes. A chart review was conducted to collect data on clinical parameters listed in - Table 2. Toxicities were graded using Common Terminology Criteria for Adverse Events (CTCAE) ${ }^{11}$ version 5.0 (-Supplementary Material 1, available in the online version). After extracting the data from the patient charts, information was manually entered into an electronic spreadsheet file, and subsequent data processing and analysis were performed using the software Stata 13. Descriptive statistics was used for continuous variables, such as age and body mass index, ${ }^{12}$ and median and interquartile ranges were reported to describe follow-up duration, dose of midline shielding, and duration of treatment. Reporting frequencies and percentages was done for categorical data variables, such as disease stage, smoking status, EBRT machine used, brachytherapy fractionation scheme, and planning technique.

Proportions per categories of the qualitative variables, such as presence of GU and/or GI toxicities, local or distant recurrences, and deaths, were computed. Point and interval estimates of these proportions were also determined. To determine exposure-specific proportions, participants who previously had clinical and treatment risk factors were further divided between those who developed the toxicities and otherwise. Odds ratios were computed for association of HDR brachytherapy exposure and outcomes of interest. A series of multiple logistic regression modeling procedures were done mainly with the adjustment for probable confounders to be
Table 2 Study parameters retrieved from the charts

\begin{tabular}{|c|c|c|}
\hline & $\begin{array}{l}\text { Study } \\
\text { parameters }\end{array}$ & Definition in this study \\
\hline \multirow[t]{4}{*}{ Primary } & $\begin{array}{l}\text { Gastrointestinal } \\
\text { toxicities }\end{array}$ & $\begin{array}{l}\text { As per CTCAE v5.0 (- Supplementary } \\
\text { Material 1, available in the online } \\
\text { version) }\end{array}$ \\
\hline & $\begin{array}{l}\text { Genitourinary } \\
\text { toxicities }\end{array}$ & $\begin{array}{l}\text { As per CTCAE v } 5.0 \text { ( }- \text { Supplementary } \\
\text { Material } 1 \text {, available in the online } \\
\text { version) }\end{array}$ \\
\hline & $\begin{array}{l}\text { Local } \\
\text { recurrence }\end{array}$ & $\begin{array}{l}\text { Recurrence limited to uterus, cervix, } \\
\text { vulvovaginal, regional lymph nodes, } \\
\text { rectum, and bladder }\end{array}$ \\
\hline & $\begin{array}{l}\text { Distant } \\
\text { recurrence }\end{array}$ & Recurrence to distant organ sites \\
\hline \multirow[t]{8}{*}{ Secondary } & OTT & $\begin{array}{l}\text { Elapsed calendar days from day } \\
1 \text { EBRT to last fraction of HDR } \\
\text { brachytherapy }\end{array}$ \\
\hline & $\begin{array}{l}\text { EBRT and } \\
\text { brachytherapy } \\
\text { interval }\end{array}$ & $\begin{array}{l}\text { Elapsed calendar days between last } \\
\text { fraction of EBRT to first fraction of } \\
\text { HDR brachytherapy }\end{array}$ \\
\hline & $\begin{array}{l}\text { EBRT machine } \\
\text { used }\end{array}$ & Cobalt or LINAC \\
\hline & $\begin{array}{l}\text { Midline } \\
\text { shielding }\end{array}$ & $\begin{array}{l}\text { Block placed after a certain dose of } \\
\text { EBRT to limit dose to the bladder } \\
\text { and rectum }\end{array}$ \\
\hline & $\begin{array}{l}\text { Brachytherapy } \\
\text { fractionation }\end{array}$ & $\begin{array}{l}\text { Prescribed dose per fraction and } \\
\text { number of brachytherapy fractions }\end{array}$ \\
\hline & $\begin{array}{l}\text { Smoking } \\
\text { history }\end{array}$ & $\begin{array}{l}\text { Yes (current or previous smoker) } \\
\text { No (no history of smoking) }\end{array}$ \\
\hline & $\begin{array}{l}\text { Body mass } \\
\text { index }\end{array}$ & $\begin{array}{l}\text { Weight }(\mathrm{kg}) / \text { height }^{2}\left(\mathrm{~m}^{2}\right) \\
\text { Cut-offs for BMI categories } \\
\left.\text { (Hsu et al }{ }^{12}\right) \\
<18.5 \text { : underweight } \\
\text { 18.5-22.9: normal } \\
\text { 23-26.9: overweight } \\
\geq 27 \text { : obese }\end{array}$ \\
\hline & $\begin{array}{l}\text { Tumor } \\
\text { persistence }\end{array}$ & $\begin{array}{l}\text { Persistence of disease despite treat- } \\
\text { ment, without evidence of remission }\end{array}$ \\
\hline
\end{tabular}

Abbreviations: BMI, body mass index; CTCAE, Common Terminology Criteria for Adverse Events; EBRT, external beam radiotherapy; HDR, high-dose-rate; LINAC, linear accelerator; OTT, overall treatment time.

conducted using select clinical variables based on the literature through the backward elimination process. An arbitrary cut-off of a change in the $p$-value less than 0.25 was used to screen for probable confounders. The level of significance for all sets of analysis was set at $p<0.05$ using two-tailed comparisons. Significance levels were adjusted for multiple comparisons performed, when necessary, using the FisherHayter post hoc method.

\section{Results}

A total of 174 patients who fit the inclusion criteria of the study received HDR intracavitary brachytherapy as part of their management for cervical cancer. Eleven patient charts were missing and not retrievable. The remaining 163 patient charts were reviewed for baseline patient-related ( - Table 3 ) 
Table 3 Baseline characteristics of the study population $(n=163)$

\begin{tabular}{|c|c|}
\hline Characteristics & Summary measures \\
\hline Median age at diagnosis (y) & $47(20-73)$ \\
\hline \multicolumn{2}{|l|}{ Smoking status } \\
\hline Nonsmokers & $133(81.60 \%)$ \\
\hline Smokers/ex-smokers & $30(18.40 \%)$ \\
\hline \multicolumn{2}{|l|}{ Body mass index } \\
\hline Normal & $73(45.34 \%)$ \\
\hline Underweight & $20(12.42 \%)$ \\
\hline Overweight & $31(19.25 \%)$ \\
\hline Obese & $37(22.98 \%)$ \\
\hline \multicolumn{2}{|l|}{ Histologic diagnosis } \\
\hline Adenocarcinoma & $41(25.15 \%)$ \\
\hline Squamous cell carcinoma & $122(74.85 \%)$ \\
\hline $\begin{array}{l}\text { Size of mass on initial internal } \\
\text { examination }(\mathrm{cm})\end{array}$ & $6 \pm 1.66(1-12)$ \\
\hline \multicolumn{2}{|l|}{ Cervical cancer stage } \\
\hline IB & $1(0.61 \%)$ \\
\hline IB1 & $2(1.23 \%)$ \\
\hline IB2 & $6(3.68 \%)$ \\
\hline IIA1 & $4(2.45 \%)$ \\
\hline IIA2 & $7(4.29 \%)$ \\
\hline IIB & $93(57.06 \%)$ \\
\hline IIIB & $50(30.67 \%)$ \\
\hline
\end{tabular}

and treatment-related ( - Table 4 ) characteristics. Although this represented only $82 \%$ of the computed sample size, which could be attributed to missing records and treatment variations, post hoc analyses revealed that the power accrued remained at $80 \%$.

The median age at diagnosis was 47 years (range: 20-73 years). Majority of the patients were nonsmokers ( $n=133,81.6 \%$ ). Most patients had normal baseline body mass index ( $n=73,45.34 \%$ ). Majority of the patients had squamous cell carcinoma histology $(n=122,74.85 \%)$. The average pretreatment size of the cervical mass was $6 \pm$ $1.66 \mathrm{~cm}$. The most common stage was IIB ( $n=93,57.06 \%)$, followed by IIIB ( $n=50,30.67 \%$ ).

Almost two-thirds of the patients received external beam irradiation via cobalt teletherapy ( $n=107,66.05 \%$ ), with the rest treated via a linear accelerator ( $n=55,33.95 \%)$ (-Table 4). The median central dose was 4,600 cGy (range: 4,000-5,400 cGy). For brachytherapy, most patients underwent a $7 \mathrm{~Gy} \times 4$ fractionation scheme ( $n=109,82.58 \%$ ), while the rest underwent an $8 \mathrm{~Gy} \times 3$ fractionation scheme ( $n=23,17.42 \%$ ). The median number of days elapsed during EBRT was 49 days (range: 21-160), while the median number of days between EBRT and brachytherapy was 57 days (range: 0-447). The median number of days elapsed to complete the brachytherapy course was 18 days (range: 10-59). The median OTT was 129 days (range: 63-541).

Patients who were unable to complete the institutionally mandated 90-day follow-up were excluded from analysis
Table 4 Treatment characteristics of the study population $(n=163)$

\begin{tabular}{|c|c|}
\hline Characteristics & Summary measures \\
\hline \multicolumn{2}{|l|}{ EBRT } \\
\hline $\begin{array}{l}\text { Cobalt-60 teletherapy } \\
\text { machine (Co-60) }\end{array}$ & 107 (66.05\%) \\
\hline LINAC & 55 (33.95\%) \\
\hline Median central dose (cGy) & $4,600(4,000-5,400)$ \\
\hline \multicolumn{2}{|l|}{ Fractionation regimen used } \\
\hline 8 Gy $\times 3$ fractions & $23(17.42 \%)$ \\
\hline 7 Gy $\times 4$ fractions & $109(82.58 \%)$ \\
\hline $\begin{array}{l}\text { Median number of days at } \\
\text { EBRT }\end{array}$ & $49(21-160)$ \\
\hline $\begin{array}{l}\text { Median EBRT and } \\
\text { brachytherapy interval (d) }\end{array}$ & $57(0-447)$ \\
\hline $\begin{array}{l}\text { Median number of days } \\
\text { elapsed at brachytherapy }\end{array}$ & $18(10-59)$ \\
\hline $\begin{array}{l}\text { Median overall treatment } \\
\text { time (d) }\end{array}$ & $129(63-541)$ \\
\hline
\end{tabular}

Table 5 Proportion of treatment outcomes $(n=132)$

\begin{tabular}{|c|c|c|}
\hline Outcomes & Frequency (\%) & $\begin{array}{l}\text { 95\% confidence } \\
\text { interval }\end{array}$ \\
\hline \multicolumn{3}{|c|}{ Median follow-up (d): 389 (95-900) } \\
\hline \multicolumn{3}{|l|}{ Treatment toxicities } \\
\hline Gastrointestinal & $26(19.70 \%)$ & \\
\hline Gr. 1 & $5(3.79 \%)$ & $1.24-8.62$ \\
\hline Gr. 2 & $14(10.61 \%)$ & $5.92-17.15$ \\
\hline Gr. 3 & $7(5.30 \%)$ & $2.16-10.62$ \\
\hline Genitourinary & $2(1.52 \%)$ & $0.07-5.70$ \\
\hline Gr. 1 & $0(0.0 \%)$ & \\
\hline Gr. 2 & $2(1.52 \%)$ & $0.07-5.70$ \\
\hline Gr. 3 & $0(0.0 \%)$ & \\
\hline Recurrences & $42(31.82 \%)$ & $23.99-40.49$ \\
\hline \multicolumn{3}{|l|}{ By location } \\
\hline Locoregional & $14(10.61 \%)$ & $5.92-17.15$ \\
\hline Distant & $17(12.88 \%)$ & $7.68-19.82$ \\
\hline $\begin{array}{l}\text { Simultaneous local } \\
\text { and distant }\end{array}$ & $11(8.33 \%)$ & $4.23-14.42$ \\
\hline \multicolumn{3}{|l|}{ By stage } \\
\hline IB & $1(0.76 \%)$ & $0.02-4.15$ \\
\hline$\| \mathrm{A}$ & $5(3.79 \%)$ & $1.24-8.62$ \\
\hline IIB & 21 (15.91\%) & $10.13-23.28$ \\
\hline IIIB & $15(11.36 \%)$ & $6.50-18.05$ \\
\hline Tumor persistence & $9(6.82 \%)$ & $3.16-12.55$ \\
\hline
\end{tabular}

of outcomes $(n=31)$. Among the remaining 132 patients (-Table 5), median follow-up was 389 days (range: 95-900). A total of 26 patients (19.70\%) experienced GI toxicities, while 
Table 6 Distribution of treatment failure sites

\begin{tabular}{|c|l|}
\hline Sites & Frequency (\%) \\
\hline Locoregional involvement & 27 \\
\hline Ovaries & $1(3.70 \%)$ \\
\hline Uterocervix & $16(59.26 \%)$ \\
\hline Vulvovaginal & $2(7.41 \%)$ \\
\hline Pelvic nodes & $6(22.22 \%)$ \\
\hline Rectosigmoid & $1(3.70 \%)$ \\
\hline Bladder and rectosigmoid & $1(3.70 \%)$ \\
\hline Distal involvement & 26 \\
\hline Bones & $4(15.38 \%)$ \\
\hline Lung involvement (total) & $9(34.62 \%)$ \\
\hline Lungs only & $5(19.23 \%)$ \\
\hline Lungs and liver & $2(7.69 \%)$ \\
\hline Liver involvement (total) & $3(11.54 \%)$ \\
\hline Liver only & $1(3.85 \%)$ \\
\hline Para-aortic involvement (total) & $11(42.31 \%)$ \\
\hline Para-aortics only & $7(26.92 \%)$ \\
\hline Para-aortics and liver & $1(3.85 \%)$ \\
\hline Para-aortics and lung & $2(7.69 \%)$ \\
\hline Para-aortics and supraclavicular node & $1(3.85 \%)$ \\
\hline Supraclavicular node involvement (total) & $4(15.38 \%)$ \\
\hline Supraclavicular node only & $3(11.54 \%)$ \\
\hline
\end{tabular}

2 patients (1.52\%) experienced GU toxicities (-Table 5). Recurrence occurred in 42 (31.82\%) of these patients, with 14 (10.61\%) recurring locoregionally, 17 (12.88\%) recurring distantly, and 11 (8.3\%) occurring both locoregionally and distantly. Nine patients $(6.52 \%)$ had tumor persistence despite treatment.

Sites of locoregional and distant failure are shown in - Table 6. The uterocervical region was the most common site of locoregional recurrence ( $n=16,59.26 \%$ ), followed by pelvic nodal ( $n=6,22.22 \%$ ) and vulvovaginal recurrence ( $n=2,7.41 \%$ ). The para-aortic nodal region was the most common site of distant failure $(n=7,26.92 \%)$. When combined with those with simultaneous failure at other organ sites, the total incidence of para-aortic involvement was $42.31 \%$ ( $n=11$ ) of all cases of distant recurrence. The lungs were the second most commonly involved distant site ( $n=9,34.62 \%)$.

Based on unadjusted logistic regression, there were no notable associations between the clinically important variables and the occurrence of GI and/or GU toxicities. On adjusted measures, a high central dose was significantly associated with the presence of toxicities $(p=0.03$ )

\section{(-Table 7).}

There were also no notable associations between the clinically important variables and treatment failure, although a longer treatment time seemed to be weakly associated $(p=0.06)$ with higher treatment failure ( - Table 8 ).

\section{Discussion}

\section{Toxicities}

GI and GU toxicities are expected complications after pelvic irradiation for treatment of gynecologic malignancies, ${ }^{13}$ but the reported incidence varies widely.

In a retrospective study by Chen et $\mathrm{al}^{14}{ }^{14} 29.7 \%$ of 128 patients with cervical cancer who received three to four fractions of 5 to $7.2 \mathrm{~Gy}$, prescribed to point $\mathrm{A}$, developed late rectal complications after a median follow-up of 43 months. Although our study showed a lower incidence of GI toxicity $(19.7 \%)$ than the study of Chen et al, the latter had a longer median follow-up duration than our study (389 days or 13 months), therefore having a longer opportunity to observe for late toxicities.

Stewart and Viswanathan ${ }^{15}$ systematically reviewed the outcomes of studies that performed HDR brachytherapy prescribed to point A in stage I to III patients with cervical cancer. The rates of grade 3 to 5 late bowel and bladder complications were 0.4 to $10 \%$ and 1.4 to $25.6 \%$ in prospective and retrospective series, respectively. Our study revealed an incidence of $5.3 \%$ grade 3 to $5 \mathrm{GI}$ and no grade 3 to $5 \mathrm{GU}$ toxicities, which is within (GI) and below (GU) the range reported by Stewart and Viswanathan. It must be noted, however, that the highest incidence of toxicities in the above series was reported by the study of Hsu et $\mathrm{al}^{16}{ }^{16}$ and was observed in the population arm that received six twice-per-day fractions of $7 \mathrm{~Gy}$, which has a higher radiobiologically equivalent total dose than the predominant regimen of four fractions of $7 \mathrm{~Gy}$ seen in our study.

In the study of Das et al, ${ }^{17} 286$ patients with cervical cancer were evaluated for toxicities and recurrences after receiving a central tumor dose of 40 Gy via Co-60 teletherapy and 21 Gy ( 7 Gy $\times 3$ fractions) to point A via Ir-192 HDR brachytherapy. In this study, $21.5 \%$ of patients developed grade 1 to 3 rectal complications, with a peak onset at 3 months, while 5.2\% of patients developed grade 1 to 3 bladder complications, which occurred at a later period of 10 to 24 months after brachytherapy. These rates may seem to be the same with the findings of our study, but majority of the rectal toxicities in the study of Das are grade $1(17.9 \%)$ versus the predominant grade 2 rectal toxicities (10.6\%) seen in our study.

A pooled analysis on brachytherapy studies published between 2000 and 2015 in the United States was recently done by Mayadev et $\mathrm{al}^{9}$ for the American Brachytherapy Task Group. It included 16 prospective and 51 retrospective studies that focused on survival outcomes, and 13 retrospective studies that focused on toxicity outcomes. The rates of late grade $3 \mathrm{GI}$ (5.3\%) and grade $3 \mathrm{GU}(0 \%)$ in our study are within the range of late grade $3 \mathrm{GI}$ and lower than the range of GU toxicities in the study of Mayadev et al, which was at 1 to $11 \%$ and 2 to $20 \%$ for GI and GU toxicities, respectively.

In our study, central tumor dose, given as a result of midline shielding, was found to be significantly associated with presence of toxicities. This might be because most of the patients underwent EBRT via Co-60 teletherapy ( $n=107,66.05 \%$ ) delivered via two-dimensional conventional technique. Midline shielding or blocking has been traditionally used 
Table 7 Crude and adjusted odds ratios of genitourinary and gastrointestinal toxicities in association with patient- and treatment-related characteristics

\begin{tabular}{|c|c|c|c|c|}
\hline & \multicolumn{2}{|c|}{ Unadjusted measures } & \multicolumn{2}{|c|}{ Adjusted measures } \\
\hline & Odds (95\% Cl) & $p$-Value & Odds (95\% Cl) & $p$-Value \\
\hline \multicolumn{5}{|l|}{ Patient-related factors } \\
\hline Age at diagnosis & $1.03(0.98-1.07)$ & 0.24 & $1.03(0.98-1.09)$ & 0.49 \\
\hline History of smoking & $0.30(0.07-1.36)$ & 0.12 & $0.08(0.01-7.39)$ & 0.26 \\
\hline \multicolumn{5}{|l|}{ Body mass index } \\
\hline Normal & 1.00 & & 1.00 & \\
\hline Underweight & $1.04(0.29-3.73)$ & 0.95 & $0.50(0.10-2.50)$ & 0.39 \\
\hline Overweight & $0.68(0.20-2.35)$ & 0.32 & $0.79(0.19-3.26)$ & 0.75 \\
\hline Obese & $1.02(0.34-3.07)$ & 0.43 & $2.27(0.59-8.66)$ & 0.23 \\
\hline \multicolumn{5}{|l|}{ Histologic diagnosis } \\
\hline Adenocarcinoma & 1.00 & & 1.00 & \\
\hline Squamous cell carcinoma & $1.99(0.63-6.25)$ & 0.24 & $1.70(0.45-6.45)$ & 0.44 \\
\hline \multicolumn{5}{|l|}{ Cervical cancer stage } \\
\hline Stage I & 1.00 & & 1.00 & \\
\hline Stage II & $0.89(0.09-8.50)$ & 0.92 & $0.33(0.02-4.43)$ & 0.41 \\
\hline Stage III & $1.21(0.12-12.12)$ & 0.87 & $0.47(0.03-7.32)$ & 0.59 \\
\hline Baseline internal examination & $0.94(0.72-1.22)$ & 0.64 & $0.73(0.50-1.08)$ & 0.12 \\
\hline \multicolumn{5}{|l|}{ Treatment-related factors } \\
\hline Overall treatment time & $1.00(0.99-1.01)$ & 0.60 & $0.99(0.98-1.01)$ & 0.28 \\
\hline Number of days at brachytherapy & $1.01(0.95-1.07)$ & 0.74 & $1.07(0.99-1.16)$ & 0.09 \\
\hline \multicolumn{5}{|l|}{ EBRT machine used } \\
\hline Co-60 & 1.00 & & 1.00 & \\
\hline LINAC & $1.10(0.45-2.70)$ & 0.83 & $0.64(0.19-2.14)$ & 0.47 \\
\hline Number of fractionations & $0.82(0.27-2.48)$ & 0.73 & $0.47(0.12-1.84)$ & 0.28 \\
\hline Central tumor dose given & $1.00(0.99-1.00)$ & 0.13 & $1.00(1.00-1.01)$ & 0.03 \\
\hline
\end{tabular}

Abbreviations: EBRT, external beam radiotherapy; LINAC linear accelerator.

during conventionally planned pelvic EBRT to boost the parametria while sparing the sigmoid, rectum, and bladder. With the advent of three-dimensional conformal radiotherapy and intensity-modulated radiotherapy, however, the value of midline shielding in sparing the relevant OARs is being questioned. ${ }^{18}$

A review of records of 3,489 International Federation of Gynecology and Obstetrics (FIGO) stage I and II patients with cervical cancer, who received EBRT and LDR brachytherapy at MD Anderson Cancer Center, found smoking history to be a significant predictor of bladder, small bowel, and rectal complications, while thin physique and obesity were associated with an increased risk of GI and bladder complications, respectively. ${ }^{19}$ In our study, presence of toxicities was not significantly associated with either smoking history or body mass index.

\section{Recurrences}

Prior to our study, Tagal et al (C.J. Tagal, MD, unpublished data, December 2018) already performed a retrospective review of recurrent cervical cancer cases from January
2012 to December 2016 in the same institution as in our study. The brachytherapy facility of this institution, however, started its shift from Cs-137 LDR brachytherapy to Co-60 HDR brachytherapy in September 2016, and thus the population in the study of Tagal et al was mainly treated with LDR brachytherapy after EBRT. We listed some differences between the two studies in - Table 9.

The median OTT in the study of Tagal et al was 77 days, which was shorter than the median OTT of 129 days of our study. This difference might be a consequence of HDR brachytherapy being multifractional and thus requiring more days to be completed. Both studies had the para-aortics as the most common site of distant recurrence, although our study had a lower incidence of para-aortic metastases (-Table $\mathbf{9}$ ).

In the aforementioned study of Das et al, ${ }^{17}$ with a median follow-up of 13 months, $25.4 \%$ of patients had locoregional recurrence, while $1.9 \%$ developed distant metastasis after a median time of 19 months. The most common site of local failure was the pelvis, while the most common site of distant failure was the lung. Although the doses delivered during EBRT and brachytherapy were lower in the study of Das et al 
132 Cervical Cancer Brachytherapy Outcomes in the Philippines Cereno et al.

Table 8 Crude and adjusted odds ratios of recurrence in association with patient- and treatment-related characteristics

\begin{tabular}{|c|c|c|c|c|}
\hline & \multicolumn{2}{|c|}{ Unadjusted measures } & \multicolumn{2}{|c|}{ Adjusted measures } \\
\hline & Odds $(95 \% \mathrm{Cl})$ & $p$-Value & Odds $(95 \% \mathrm{Cl})$ & p-Value \\
\hline \multicolumn{5}{|l|}{ Patient-related factors } \\
\hline Age at diagnosis & $1.00(0.97-1.04)$ & 0.80 & $1.00(0.96-1.04)$ & 0.93 \\
\hline History of smoking & $1.23(0.49-3.08)$ & 0.65 & $1.16(0.43-3.13)$ & 0.77 \\
\hline \multicolumn{5}{|l|}{ Body mass index } \\
\hline Normal & 1.00 & & 1.00 & \\
\hline Underweight & $1.64(0.56-4.79)$ & 0.37 & $2.22(0.65-7.57)$ & 0.20 \\
\hline Overweight & $0.59(0.20-1.68)$ & 0.32 & $0.62(0.19-2.04)$ & 0.43 \\
\hline Obese & $1.45(0.58-3.60)$ & 0.43 & $1.47(0.52-4.10)$ & 0.47 \\
\hline \multicolumn{5}{|l|}{ Histologic diagnosis } \\
\hline Adenocarcinoma & 1.00 & & 1.00 & \\
\hline Squamous cell carcinoma & $1.01(0.44-2.33)$ & 0.97 & $1.04(0.40-2.70)$ & 0.94 \\
\hline \multicolumn{5}{|l|}{ Cervical cancer stage } \\
\hline Stage I & 1.00 & & 1.00 & \\
\hline Stage II & $2.46(0.27-22.02)$ & 0.42 & $2.32(0.23-23.42)$ & 0.47 \\
\hline Stage III & $2.96(0.32-27.67)$ & 0.95 & $2.07(0.19-23.01)$ & 0.59 \\
\hline Baseline internal examination & $1.13(0.91-1.40)$ & 0.28 & $1.20(0.93-1.54)$ & 0.17 \\
\hline \multicolumn{5}{|l|}{ Treatment-related factors } \\
\hline Overall treatment time & $1.01(1.00-1.02)$ & 0.10 & $1.01(1.00-1.02)$ & 0.06 \\
\hline Number of days at brachytherapy & $1.02(0.97-1.07)$ & 0.52 & $0.99(0.92-1.06)$ & 0.74 \\
\hline \multicolumn{5}{|l|}{ EBRT machine used } \\
\hline Co-60 & 1.00 & & 1.00 & \\
\hline LINAC & $0.84(0.39-1.83)$ & 0.67 & $1.01(0.41-2.49)$ & 0.98 \\
\hline Number of fractionations & $2.17(0.75-6.29)$ & 0.15 & $2.22(0.68-7.28)$ & 0.19 \\
\hline Central tumor dose given & $1.00(0.99-1.01)$ & 0.35 & $1.00(0.99-1.00)$ & 0.77 \\
\hline
\end{tabular}

Abbreviations: EBRT, external beam radiotherapy; LINAC linear accelerator.

Table 9 Differences between the two retrospective studies in the study institution

\begin{tabular}{|l|l|l|}
\hline Parameters & Tagal et al, 2018 & $\begin{array}{l}\text { Cereno et al, 2019 } \\
\text { (current study) }\end{array}$ \\
\hline Population $(n)$ & 59 & $163^{\mathrm{a}} / 132^{\mathrm{b}}$ \\
\hline Age at diagnosis (y) & 47 (average) & 47 (median) \\
\hline Average pretreatment size of cervical mass (cm) & 5 & 6 \\
\hline Median overall treatment time (d) & 77 & 129 \\
\hline Number of recurrent cases & 59 & 53 \\
\hline Recurrence occurring at locoregional sites & $47(79.66 \%)$ & $27(50.94 \%)$ \\
\hline Recurrence occurring at distant sites & $35(59.32 \%)$ & $26(49.06 \%)$ \\
\hline Recurrence involving the para-aortic lymph nodes & $21(35.59 \%)$ & $11(20.75 \%)$ \\
\hline
\end{tabular}

aSample size for the descriptive parameters.

bSample size for the analytic parameters. 
than the doses delivered in our institution, their recurrence rates are lower than those in our study. The former study, however, was not able to report on their OTT, which was found to be suboptimal in our study (median of 129 days).

Prolonged OTT has long been established as associated with inferior local control and survival, with the ideal duration being 8 weeks or 56 days. ${ }^{20}$ Among all patient- and treatment-related factors in our study, OTT was weakly associated with presence of recurrence. It should be noted, however, that none of the included patients was able to satisfy the ideal OTT of 56 days.

\section{Conclusion and Recommendations}

We report institutional outcomes on toxicities and recurrences after HDR brachytherapy in patients with cervical cancer. Our study suggests that central tumor dose, as a result of midline shielding, is significantly associated with toxicities, while OTT is weakly associated with recurrence. This study also demonstrates the safety of using cobalt-60 sources for HDR brachytherapy.

To our knowledge, this is the first study to formally report on local brachytherapy outcomes in the Philippines. Efforts should be made to manage outcome biases, such as prolonged OTT, in future researches and policies in low-resource, high-volume brachytherapy centers in the country.

\section{Note}

All data generated and analyzed during this study are included in this published article and - Supplementary Materials $\mathbf{1}$ and $\mathbf{2}$ (available in the online version).

\section{Conflict of Interest}

None declared.

\section{Acknowledgments}

The authors would like to thank Alvin Duke R. Sy, RN, University of the Philippines-Philippine General Hospital, Ermita, Manila, Philippines, for statistical analysis.

\section{References}

1 National Comprehensive Cancer Network (NCCN). Cervical cancer (Version 1.2017). 2017. Available at: https://www. nccn.org/professionals/physician_gls/pdf/cervical.pdf. Accessed February 21, 2019

2 Society of Gynecologic Oncologists of the Philippines (SGOP). Cervical cancer. In: Clinical Practice Guidelines. 3rd ed. Manila: OVT-Graphic Line, Inc; 2018 1-35

3 Viswanathan AN. Uterine cervix. In: Halperin EC, Wazer DE, Perez CA, Brady LW. Principles and practice of radiation oncology. 6th ed. Philadelphia: Wolters Kluwer; 2013:1355-1425

4 Karlsson J, Dreifaldt AC, Mordhorst LB, Sorbe B. Differences in outcome for cervical cancer patients treated with or without brachytherapy. Brachytherapy 2017;16(1):133-140

5 Viswanathan AN, Erickson BA. Three-dimensional imaging in gynecologic brachytherapy: A survey of the American
Brachytherapy Society. Int J Radiat Oncol Biol Phys 2010;76(1):104-109

6 Orton CG, Seyedsadr M, Somnay A. Comparison of high and low dose rate remote afterloading for cervix cancer and the importance of fractionation. Int J Radiat Oncol Biol Phys 1991;21(6):1425-1434

7 Viswanathan AN, Beriwal S, De Los Santos JF, et al; American Brachytherapy Society. American Brachytherapy Society consensus guidelines for locally advanced carcinoma of the cervix. Part II: high-dose-rate brachytherapy. Brachytherapy 2012;11(1):47-52

8 Viswanathan AN, Creutzberg CL, Craighead P, et al. International brachytherapy practice patterns: A survey of the Gynecologic Cancer Intergroup (GCIG) Int J Radiat Oncol Biol Phys 2012;82(1):250-255

9 Mayadev J, Viswanathan A, Liu Y, et al. American Brachytherapy Task Group Report: A pooled analysis of clinical outcomes for high-dose-rate brachytherapy for cervical cancer. Brachytherapy 2017;16(1):22-43

10 Ntekim A, Adenipekun A, Akinlade B, Campbell O. High dose rate brachytherapy in the treatment of cervical cancer: Preliminary experience with cobalt 60 radionuclide source-A prospective study. Clin Med Insights Oncol 2010;4:89-94

11 U.S. Department of Health and Human Services. Common terminology criteria for adverse events (CTCAE) version 5.0. 2017. Available at: https://ctep.cancer.gov/protocoldevelopment/electronic_applications/docs/CTCAE_v5_Quick_ Reference_5x7.pdf. Accessed February 27, 2019

12 Hsu WC, Araneta MR, Kanaya AM, Chiang JL, Fujimoto W. BMI cut points to identify at-risk Asian Americans for type 2 diabetes screening. Diabetes Care 2015;38(1):150-158

13 Viswanathan AN, Lee LJ, Eswara JR, et al. Complications of pelvic radiation in patients treated for gynecologic malignancies. Cancer 2014;120(24):3870-3883

14 Chen SW, Liang JA, Yang SN, Liu RT, Lin FJ. The prediction of late rectal complications following the treatment of uterine cervical cancer by high-dose-rate brachytherapy. Int J Radiat Oncol Biol Phys 2000;47(4):955-961

15 Stewart AJ, Viswanathan AN. Current controversies in highdose-rate versus low-dose-rate brachytherapy for cervical cancer. Cancer 2006;107(5):908-915

16 Hsu WL, Wu CJ, Jen YM, et al. Twice-per-day fractionated high versus continuous low dose rate intracavitary therapy in the radical treatment of cervical cancer: A nonrandomized comparison of treatment results. Int J Radiat Oncol Biol Phys 1995;32(5):1425-1431

17 Das D, Chaudhuri S, Deb AR, Aich RK, Gangopadhyay S, Ray A. Treatment of cervical carcinoma with high-dose rate intracavitary brachytherapy: Two years follow-up study. Asian Pac J Cancer Prev 2011;12(3):807-810

18 Viswanathan AN. Uterine cervix. In: Halperin EC, Wazer DE, Perez CA, Brady LW. Principles and practice of radiation oncology. 6th ed. Philadelphia: Wolters Kluwer; 2013:1355-1425

19 Eifel PJ, Jhingran A, Bodurka DC, Levenback C, Thames H. Correlation of smoking history and other patient characteristics with major complications of pelvic radiation therapy for cervical cancer. J Clin Oncol 2002;20(17):3651-3657

20 Viswanathan AN, Thomadsen B; American Brachytherapy Society Cervical Cancer Recommendations Committee. American Brachytherapy Society. American Brachytherapy Society consensus guidelines for locally advanced carcinoma of the cervix. Part I: general principles. Brachytherapy 2012;11(1):33-46 